\title{
Pola Hubungan Antara Jumlah Kelahiran Dengan Jumlah Betina dan Pejantan Produktif Pada Ternak Sapi
}

\author{
BASIR PALY \\ Jurusan Peternakan, Fakultas Sains dan Teknologi, UIN Alauddin Makassar \\ Jl. Sultan Alauddin 36 Samata, Kab. Gowa 92113 \\ email: basirpaly@gmail.com
}

\begin{abstract}
This research aims to know the pattern of the relationship between the number of births and the number of males and females productive. Implemented in the Gowa in June-October 2014. Using method of survey through observation and interview. The population of the research was a whole group of cattle there. As many as 5 group of cattle has been observed and interviewed. Variables are observed and analyzed are: (1) the number of cattle owned by males and females, (2) the number of births, (3) the number of males and females productive, (4) sales, cut withholding, and cases of death, and (5) number of females productive female rescue. Data analysis was carried out in two categories, descriptive and inferensial. Descriptive analysis using a matrix, tabulate and a chart, while inferential analysis using SPSS and Amos 16 software, then validated with data and information from other sources. The results showed that there are four variables that are directly related to the number of births. Namely: (1) the number of female productive, (2) number of females sold, cut withholding, and death, (3) number of productive female rescue, and (4) the number of male productive. To four variables are also interrelated with one another, but not directly related to the number of births. This powerful relationship patterns indicate that the number of births is very closely related to the number of productive female rescue, and the number of males. While the weak relationship patterns indicate that the number of females sold, cut withholding, and the dead, is not related to the number of births.
\end{abstract}

Keywords: birth, females, males, relationships

\section{PENDAHULUAN}

Impor daging sapi dan sapi bakalan telah berlangsung sejak Tahun 1988 hingga kini, dengan jumlah yang terus meningkat. Anehnya, jika impor dikurangi, maka populasi sapi lokal (rakyat) cenderung menurun (Haris, 2010, Dirjen Pronak, 2013 dan Kompas, 2013). Penurunan populasi tersebut bahkan dibarengi dengan pejualan dan pemotongan betina produktif (Prayogo, 2002 dan Dirjennak, 2010). Hal ini juga menunjukkan betapa rendahnya angka kelahiran dan populasi ternak sapi nasional dibanding tuntutan kebutuhan. Tidak terkecuali ternak sapi yang ada di wilayah Kabupaten Gowa.

Sejak lama pemerintah telah mendorong pertumbuhan populasi sekaligus perbaikan mutu genetik sapi melalui teknologi kawin suntik atau Inseminasi Buatan (IB). Namun, hasil evaluasi di beberapa wilayah seperti lampung, Jjawa Barat, dan Jawa Timur menunjukkan bahwa realisasi pelaksanaan IB masih sekitar 30-50\% dari potensi akseptor (Ifar, 2010 dan Ilham, 2011).

Selain itu, ditemukan bahwa efisiensi reproduksi sapi masih relatif rendah (sekitar 60 persen dari potensi efisiensi reproduksi). Hal ini disebabkan karena berbagai faktor seperti keterlambatan diagnosa birahi dari peternak, gangguan organ reproduksi, kualitas pakan yang rendah, dan kesalahan teknis dari para inseminator (Affandy et al, 2007 dan Kaharuddin, et al 2010). Akibatnya laju pertumbuhan populasi juga relatif lambat dibandingkan dengan laju pertumbuhan permintaan daging sapi.

Di Kabupaten Gowa, permasalahan utama dalam pengembangan ternak sapi adalah Percepatan Pertumbuhan Populasi. Dalam kurun waktu enam tahun terakhir (2008-2013), populasi ternak sapi tumbuh rata $10.98 \%$ per tahun. Angka cukup lumayan jika dibandingkan dengan keseluruhan jumlah populasi yang ada. Namun jika pertumbuhan 
ini mau dipercepat atau ditingkatkan lagi, maka perlu keterkaitan antara jumlah pejantan dan betina produktif yang ada dalam populasi tersebut

Yusdja et al., (2011) melaporkan bahwa penyebab rendahnya pertumbuhan populasi ternak sapi antara lain adalah; (1) proporsi jumlah pejantan dan betina produktif, (2) produktivitasbetina produktif, (3) jumlah penjualan dan pemotongan betina produktif, dan (4) adanya kasus kematian akibat penyakit hewan.

Seperti halnya daerah lain, Kabupaten Gowa juga memiliki potensi yang cukup besar untuk pengembangan peternakan sapi potong (Syamsu et al, 2006, Anonymous, 2009, dan Sonjaya, 2010). Ditinjau dari sosio-kultural, pemeliharaan ternak sapi telah diusahakan secara turun-temurun oleh masyarakat di provinsi ini. Tersedia dukungan sumber daya lokal, seperti: (1) ketersedian bahan baku pakan dari hasil limbah pertanian, seperti jerami, dedak, dan sejenisnya, (2) ketersedian sarana peternakan yang representatif seperti $\mathrm{RPH}$, pasar hewan, dan Puskewan, (3) infrastruktur pendukung baik jalan, transportasi, pelabuhan laut antar pulau, dan (4) letak geografis yang strategis dalam perdagangan komoditi peternakan di kawasan Timur Indonesia.

Namun, tantangan yang dihadapi dalam peningkatan populasi ini antara lain adalah (Aninimous, 2009): (1) Rendahnya kelahiran atau produktivitas, (2) Kurangnya bibit pejantan dan betina berkualitas, (3) Rendahnya keterampilan dan pengetahuan peternak dalam budidaya ternak sapi, (4) Maraknya penjualan dan pemotongan betina peroduktif, dan (5) Adanya kasus penyakit hewan yang menyerang sebagaian besar betina produktif.

Sehubungan dengan itu, maka penelitian ini bertujuan untuk mengetahui sejauh mana hubungan antara jumlah kelahiran dengan jumlah pejantan dan betina produktif yang ada, kurun waktu 2008-2013 di Kabupaten Gowa.

\section{METODE}

Penelitian ini dilaksanakan di Kabupaten Gowa. Pemilihan lokasi ini didasarkan pada pertimbangan bahwa kabupaten tersebut merupakan wilayah pengembangan ternak sapi dengan jumlah populasi sekitar 102,340 ekor, atau sekitar $9 \%$ dari total populasi ternak sapi yang ada Sulawesi Selatan.

Jenis penelitian ini adalah kuantitatif. Sedangkan metode yang digunakan adalah metode survey. Populasi atau subyek yang menjadi sasaran dalam studi ini adalah keseluruhan kelompok/peternak sapi yang ada di wilayah penelitian. Jumlah kelompok ternak yang ada di kabupaten Gowa adalah 21 kelompok. Jumlah sampel kelompok ternak yang diamati sebanyak 5 kelompok. Lokasi kelompok sampel di setiap kabupaten ada yang seluruhnya terletak di satu kecamatan, tetapi ada juga yang terpisah di dua kecamatan yang berbatasan.

Pengumpulan data dan informasi dilakukan melalui pengamatan dan wawancara mendalam dengan menggunakan daftar pertanyaan (kuisioner) yang terstruktur. Kuesioner disusun berdasarkan pertanyaan kunci yang harus digali di lapangan melalui subyek peternak. Priodesasi waktu dari data dan informasi yang dikumpulkan adalah mulai dari Tahun 2008 sampai dengan Tahun 2013.

Ada 5 variabel yang diamati dan dianalisis dalam penelitian ini. Yaitu: (1) Jumlah ternak jantan dan betina yang dimiliki, (2) Jumlah kelahiran, (3) Jumlah pejantan dan betina produktif, (4) Penjualan, pemotongan, dan kasus kematian, dan (5) Jumlah betina produktif yang diselamatkan. Selanjutnya data dari ke 5 varibel ini dianalisis dan interpretasi secara sistimatis.

Analisis data dilakukan dalam dua kategori, yaitu secara deskriptif dan inferensial. Analisis deskriptif menggunakan sistem tabulasi matriks dan grafik. Sedangkan anlisis inferensial menggunakan software SPSS 16 dan Amos 16. Berkaitan dengan pola hubungan kelahiran dengan pejantan dan betina produktif, sebagai tujuan penelitian ini, dilakukan analisis deskriptif. Kemudian dilanjutkan dengan analisis korelasi dengan menggunakan SPSS 16 dan Amos 16.

Hasil analisis ini, kemudian divalidasi dengan data dan informasi yang berasal dari sumber lain, khususnya dari Dinas Peternakan dan perikanan Kabupaten Gowa. 

HASIL

Tabel 1. Jumlah Populasi Pejantan dan Betina Semua Umur

\begin{tabular}{rrrrrr}
\hline Pejantan & \multicolumn{3}{c}{ Betina } & \multicolumn{3}{c}{ Jum Populasi } \\
\hline Ekor & $\%$ & Ekor & $\%$ & Ekor & $\%$ \\
\hline 16,331 & $28.06 \%$ & 41,871 & $71.94 \%$ & 58,202 & $100.00 \%$ \\
\hline 18,766 & $30.12 \%$ & 43,531 & $69.88 \%$ & 62,297 & $100.00 \%$ \\
\hline 21,126 & $31.34 \%$ & 46,287 & $68.66 \%$ & 67,413 & $100.00 \%$ \\
\hline 22,753 & $31.89 \%$ & 48,603 & $68.11 \%$ & 71,356 & $100.00 \%$ \\
\hline 27,001 & $31.29 \%$ & 59,293 & $68.71 \%$ & 86,294 & $100.00 \%$ \\
\hline 32,666 & $31.92 \%$ & 69,674 & $68.08 \%$ & 102,340 & $100.00 \%$ \\
\hline 23,107 & $30.77 \%$ & 51,543 & $69.23 \%$ & 74,650 & $100.00 \%$ \\
\hline
\end{tabular}

Tabel 2. Jumlah Kelahiran dari Pejantan dan Betina Produktif

\begin{tabular}{|c|c|c|c|c|c|c|}
\hline \multirow[t]{2}{*}{ Tahun } & \multicolumn{2}{|c|}{ Jumlah Kelahiran } & \multirow{2}{*}{$\begin{array}{l}\text { Jantan Produktif } \\
\text { (ekor) }\end{array}$} & \multicolumn{3}{|c|}{ Betina Produktif (ekor) } \\
\hline & Ekor & $\%$ & & Jumlah & Jual/Ptg/Mati & Diselamatkan \\
\hline (1) & (2) & (3) & $(4)$ & $(5)$ & $(6)$ & $(7)$ \\
\hline 2008 & 14,545 & $57.60 \%$ & 16.311 & 25,251 & 1,068 & 0 \\
\hline 2009 & 15,960 & $57.85 \%$ & 18,766 & 27,588 & 1,162 & 0 \\
\hline 2010 & 18,079 & $58.55 \%$ & 21,126 & 30,879 & 981 & 634 \\
\hline 2011 & 20,719 & $60.12 \%$ & 22,753 & 34,463 & 846 & 880 \\
\hline 2012 & 25,158 & $60.25 \%$ & 27,001 & 41,756 & 1,079 & 1,026 \\
\hline 2013 & 30,666 & $61.33 \%$ & 32,666 & 50,002 & 1,233 & 1,324 \\
\hline Rataan & 20.855 & $59.28 \%$ & 23,107 & 34,990 & 1,062 & 966 \\
\hline
\end{tabular}

Keterangan: Jumlah kelahiran (ekor dan \%) pada kolom 2 dan 3 adalah jumlah anak sapi yang lahir dari jumlah pejantan (kolom 4) dan betina produktif (kolom 5), serta dari jumlah betina produktif yang Jual/Potong/Mati (kolom 6), dan dari jumlah betina produktif yang diselamatkan (kolom 7) pada tahun bersangkutan

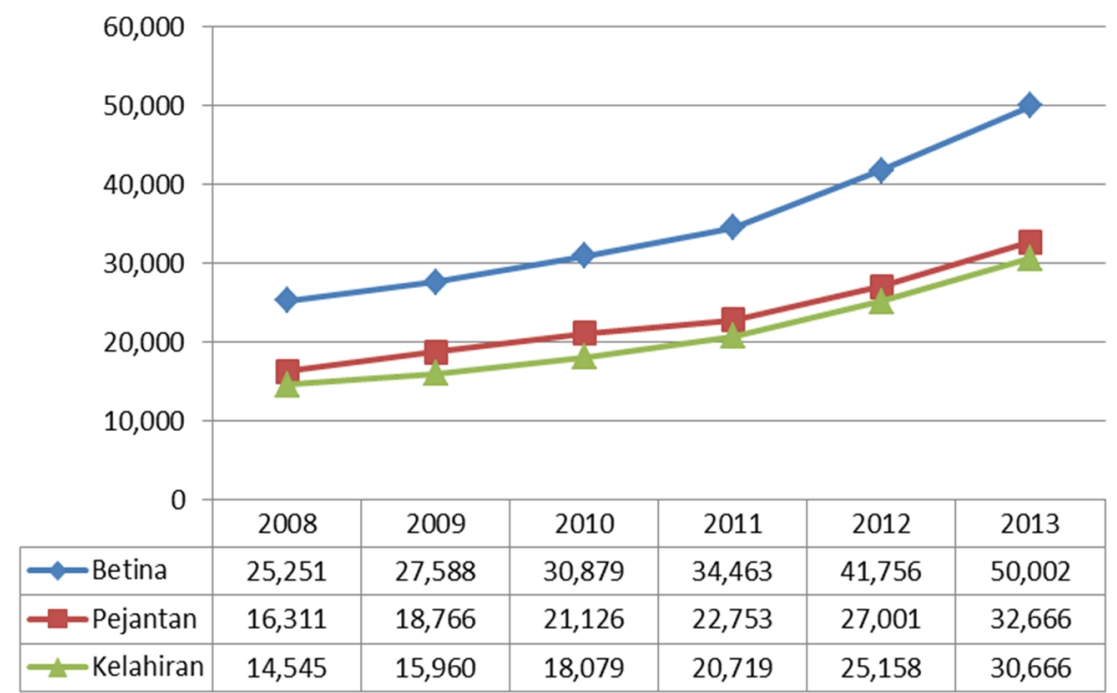

Gambar 1. Kurva ilustrasi pola hubungan antara jumlah kelahiran dengan jumlah pejantan dan betina produktif

Tabel 3. Korelasi antara Jumlah Kelahiran dengan Pejantan dan Betina Produktif

\begin{tabular}{|c|c|c|c|c|c|}
\hline & $\begin{array}{l}\text { Jum } \\
\text { Kelahiran }\end{array}$ & $\begin{array}{l}\text { Betina } \\
\text { Produktif }\end{array}$ & $\begin{array}{l}\text { Jual } \\
\text { /Ptg/Mati }\end{array}$ & Diselamatkan & $\begin{array}{l}\text { Jum } \\
\text { Pejantan }\end{array}$ \\
\hline Jum Kelahiran & 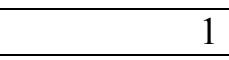 & $.658(* *)$ & -.217 & $.684(* *)$ & $.601(* *)$ \\
\hline Juml Betina Produktif & $.658(* *)$ & 1 & .005 & $.613(* *)$ & $.719(* *)$ \\
\hline Penjualan/Ptg/Mati & -.217 & .005 & 1 & -.105 & .061 \\
\hline
\end{tabular}




\begin{tabular}{lrrrrr}
\hline Diselamatkan & $.684(* *)$ & $.613(* *)$ & -.105 & 1 & .295 \\
\hline Pejantan & $.601(* *)$ & $.719(* *)$ & .061 & .295 & 1 \\
\hline
\end{tabular}

** Correlation is significant at the 0.01 level (2-tailed).

Tabel 4. Pola Hubungan antara Jumlah Kelahiran dengan Pejantan dan Betina Produktif

\begin{tabular}{ll}
\hline Pola Hubungan & Koefisien, $\mathrm{r}$ \\
\hline Hubungan Kuat: & \\
1. Jum Kelahiran $\leftrightarrow$ Betina Produktif & 0.658 \\
2. Jum Kelahiran $\leftrightarrow$ Penyelamatan Betina Produktif & 0.684 \\
3. Jum Kelahiran $\leftrightarrow$ Pejantan Produktif & 0.601 \\
4. Jum Betina Produktif $\rightarrow$ Penyelamatan Betina & 0.613 \\
5. Jum Betina Produktif $\leftarrow$ Jum Pejantan Produktif & 0.719 \\
\hline Pola Hubungan Lemah: & \\
1. Jual/Ptg/Mati $\leftrightarrow \rightarrow$ Jum Pejantan Produktif & 0.061 \\
2. Jum Pejantan Produktif $\rightarrow$ Penyelamatan Betina Pro & 0.295 \\
3. Jum Betina Produktif $\leftarrow \rightarrow$ Jum Jual/Ptg/Mati & 0.005 \\
\hline Pola Hubungan Lemah dan Negatif & \\
1. Jum Kelahiran $\rightarrow$ Jum Jual/Ptg/Mati & -0.217 \\
2. Jum Jual/Ptg/Mati $\rightarrow$ Penyelamatan Betina Pro & -0.105
\end{tabular}

\section{PEMBAHASAN}

Perbandingan Pejantan dan Betina. Ada dua hal yang menjadi pertimbangan sehingga diperlukan perbandingan antara jumlah pejantan dengan betina. Pertama, untuk mengetahui potensi genetik ternak bersangkutan (Kementan, 2012). Apabila jumlah pejantan lebih besar dari jumlah betina, maka pertumbuhan populasi ternak cenderung menurun atau stagnan. Sebaliknya, jika jumlah betina lebih besar dari jumlah pejantan, maka pertumbuhan populasi memiliki potensi yang lebih baik. Kedua, Perbandingan jumlah pejantan dan betina mencerminkan sistem pengusahaan ternak itu sendiri (KementanBPS, 2011). Jumlah betina lebih besar dari pejantan, umumnya ditemukan pada peternakan yang mengarah kepada sistem komersial. Sebaliknya, jumlah pejantan yang lebih banyak ditemukan pada sistem peternakan tradisional. Pada sistem ini, pejantan memang dipelihara sedemikian rupa sebagai penarik bajak dan transportasi hasil pertanian, mengingat pejantan jauh lebih kuat dari betina. Pada sistem tradisional ini, kepemilikan pejantan yang kuat (sapi atau kerbau) merupakan status sosial dan simbol kejayaan seseorang. Di Madura, yang terkenal dengan adu karapan sapi, kepemilikan sapi pejantan merupakan simbol dari status yang lebih tinggi.
Berdasarkan data pada Tabel 1, menunjukkan bahwa dalam enam tahun terakhir (2008-2013), rata-rata jumlah pejantan $30.77 \%$, sedangkan jumlah betina $69.23 \%$. Apabila menggunakan perbandingan, maka dapat dituliskan angka 1:2,5. Artinya, bahwa dalam setiap ekor pejantan, terdapat 2.5 ekor betina. Atau realitasnya di lapangan untuk setiap ekor pejantan, terdapat 2 atau 3 ekor betina.

Hasil perbandingan ini dapat diinterprestasikan bahwa peternakan sapi di Kabupaten Gowa memiliki potensi genetik yang baik. Dengan pengertian lain, memiliki potensi pertumbuhan populasi yang cenderung meningkat. Seakan para peternak menyadari bahwa usaha peternakan sapi, harus didasarkan pada tindakan perbanyakan atau pertumbuhan populasi. Bukan lagi dengan sistem tradisional, dimana ternak sapi digunakan sebagai penarik bajak dan transportasi hasil pertanian. Secara rasional pertumbuhan populasi memang lebih menjanjikan peningkatan pendapatan bagi peternak ketimbang sebagai tenaga penarik bajak dan transportasi hasil pertanian (Hermanto dan Swastika, 2011).

Jumlah Kelahiran. Melalui perbandingan jumlah pejantan dengan betina, maka analisis selanjutnya adalah menentukan jumlah pejantan dan betina produktif yang ada. 
Yang termasuk kategori pejantan produktif adalah sapi pejantan dewasa kelamin umur 1518 bulan (Kementan, 2012). Sapi jantan pada umur ini benar-benar sudah dewasa kelami, atau mampu mengawini dan membuahi ternak betina. Sedangkan betina produktif adalah sapi betina dewasa kelamin umur 18 bulan ke atas (Kementan, 2012). Sapi betina pada umur tersebut umumnya sudah memperlihatkan tanda-tanda birahi, minta dikawinkan. Sudah memiliki alat reproduksi yang mampu mealkukan konsepsi kebuntingan sampai melahirkan anak. Oleh karena itu, yang harus diidentifikasi dalam penelitian ini adalah jumlah pejantan dan betina produktif. Kedua variabel inilah yang paling dominan menentukan kelahiran. Betina produktif yang dijual, dipotong, dan mati karena kasus penyakit, dan yang diselamatkan merupakan variabel yang ikut mempengaruhi kelahiran secara tidak langsung. Tidak langsung di sini diakarenakan lebih mengarah kepada pengurangan dan atau penambahan betina produktif saja. Penjualan, pemotongan, dan kematian, akan mengurangi, sedangkan penyelamatan menambah jumlah betina produktif yang ada.

Pencegahan penjualan, pemotongan, kematian dan penyelamatan betina produktif ini, merupaka tindakan pemerintah Kabupaten Gowa yang sudah terprogram sejak Tahun 2009. Berdasarkan penuturan Dinas Peternakan dan Perikanan Gowa, selama program tersebut berlangsung, persentase penjualan, pemotongan, dan kematian betina produktif berhasil ditekan. Sedangkan jumlah betina produktif yang diselamatkan cenderung meningkat.

Tabel 2 menjelaskan bahwa selama 6 tahun terakhir (2008-2013), jumlah kelahiran sapi di Kabupaten Gowa mengalami peningkatan dari 14,545 ekor (2008) menjadi 30,666 ekor di Tahun 2013, atau rata-rata 20,855 per tahun. Peningkatan kelahiran ini didukung oleh jumlah betina produktif yang meningkat dari 25,251 ekor di Tahun 2008 menjadi 50,002 ekor di Tahun 2013. Oleh jumlah pejantan produktif yang juga meningkat dari 16.311 ekor di Tahun 2008, menjadi 32,666 ekor di Tahun 2013. Meskipun jumlah betina produktif yang dijual, dipotong, dan mati cenderung stagnan (tidak menurun), namun jumlah betina produktif yang berhasil diselamatkan meningkat dari 634 ekor di Tahun 2010 menjadi 1,324 ekor di Tahun 2013.

Pada Gambar 1 terlihat bahwa kurva jumlah kelahiran dengan jumlah pejantan dan betina produktif berbanding lurus. Dengan kata lain bahwa semakin tinggi jumlah pejantan dan atau betina produktif, semakin tinggi pula jumlah kelahiran. Kedudukan kurva betina produktif jauh di atas kurva kelahiran dan kurva pejantan produktif. Sementara kedudukan kurva pejantan produktif berimpit atau berada sidikit di atas kurva kelahiran. Keadaan ini menunjukkan bahwa jumlah pejantan produktif lebih banyak dari jumlah kelahiran. Namun tidak bisa dinyatakan bahwa semakin banyak jumlah pejantan semakin banyak pula angka kelahiran. Karena secara teoritis, seekor pejantan mampu melayani sampai 10 ekor betina produktif. Kedudukan kurva pejantan di bawah kurva betina produktif memang sudah tepat. Namun secara teoritis kurva pejantan disamping berada jauh di bawah kurva betina produktif, juga seharusnya berada di bawa kurva kelahiran.

Terhadap fenomena perilaku ketiga kurva ini melahirkan tiga tafsiran yang mungkin terjadi di tingkat peternak di lapangan. Pertama, Kemungkinan pertama adalah penyebaran jumlah pejantan yang tidak proporsional. Dalam artian ada sejumlah kelompok betia produktif yang dikawal oleh pejantan dengan perbandingan yang cukup, misalnya 1 pejantan dengan 3-5 ekor betina produktif. Namun di pihak lain ada juga kelompok betina produktif yang miskin pejantan, misalnya 1 pejantan mengawal 6-10 ekor betina produktif. Bahkan dimungkinkan juga adanya sekelompok kecil betina produktif yang tidak dikawal oleh seekor pejantan sekali pun, sehingga tidak ada kesempatan betina produktif untuk kawin pada saat terjadi birahi. Betina produktif yang miskin pejantan dan yang sama sekali tidak memiliki pejantan, mengakibatkan rendahnya kelahiran akumulatif dari jumlah betina produktif yang 
ada. Sebenarnya hal ini bisa teratasi pada sistem padang pengembalaan campuran di areal tertentu. Dimana pejantan dan betina produktif saling berinteraksi, khususnya pada saat birahi. Namun, di kabupaten Gowa sistem penggembalaan seperti yang dimaksudkan tidak ada lagi. Peternak secara sendiri-sendiri memelihara ternak, dan diberi pakan di dalam kandang masing-masing. Kadang-kadang melepas ternaknya pada areal tertentu yang relatif terbatas sehabis panen. Akibatnya ternak mereka kurang berinteraksi dengan kelompok ternak lainnya yang memiliki pejantan yang lebih banyak. Kedua, Kemungkinan kedua adalah tindakan peternak yang kurang perduli kepada ternak betinya yang minta kawin meski dalam keadaan birahi. Di wilayah penelitian ada seorang peternak (BDB 47 tahun) yang hanya memiliki 3 ekor betina produktif. Sapi jantan milik BDB selalu dijual di bawah usia produktif (umur di bawah 1, 5 tahun) karena harganya cukup mahal. Namun BDB cukup perduli dengan ke tiga betina produktifnya itu. Ia sering membawa ternak betinya itu ke peternak tetangganya yang memiliki pejantan. Bahkan pernah ia meminjam pejantan tetangganya itu berharihari hanya untuk kepentingan ternak betinya. Alhasil BDB dengan ketiga ternak betinanya itu rata-rata memperoleh seekor anak sapi setiap tahunnya. Sayangnya tidak banyak peternak yang mengikuti tindakan BDB ini, sehingga realitas di lapangan memperlihatkan kurva dimana pejantan berada di atas kurva kelahiran. Ketiga, Kemungkinan ketiga adalah betina produktif yang kurang subur (infertile). Dalam pengertian lain bahwa meskipun ternak betinanya telah dikawinkan dengan pejantan sekali dua kali, namun tidak juga terjadi pembuahan (conception). Hal ini terkait dengan tingkat kesehatan ternak betina itu sendiri. Penelitian yang dipaorkan oleh (Riayanto, 2010) melaporkan bahwa ketidaksuburan betina produktif, selain disebabkan oleh status kesehatan, juga ditentukan oleh tingkat ketepatan waktu kawin, yang harus dituntun oleh peternak.

Ada saat-saat tertentu dimana betina meminta kawin, dan peternak harus segera bertindak mengawinkan ternaknya, atau mempertemukan dengan pejantan produktif. Nampaknya laporan penelitian ini masih mengharuskan campur tangan manusia (peternak) dalam peningkatan angka kelahiran ternak sapi. Ada benarnya juga bahwa peningkatan kelahiran, teristimewa dalam proses perkawinan ternak, dibutuhkan campur tangan manusia yang terampil. Hanya saja persoalan ini lebih kepada kapasitas SDM (sumber daya manusia) dan kelembagaannya.

Pola Hubungan. Pada uraian sebelumnya telah digambarkan bahwa ada hubungan antara jumlah kelahiran dengan jumlah pejantan dan betina produktif dalam periode yang sama (Tabel 2 dan Gambar 1). Diperlukan analisis korelasi diantara variable-variabel yang memiliki hubungan yang dimaksud. Table 3 menyajikan koefesien korelasi antara jumlah kelahiran dengan jumlah pejantan dan betina produktif. Data yang disajikan pada Tabel 3 adalah hasil pengolahan data yang menggunakan software SPSS 16. Tabel 3 menyajikan korelasi multi-arah terhadap ke lima variabel yang dianalisis. Karena itu, untuk memudahkan pengamatan terhadap pola-pola hubungan yang terjadi, termasuk kekuatan hubungan, yang ditandai dengan nilai koefisien masing-masing variabel, maka Tabel 3 ini diformat menjadi Tabel 4. Dengan Tabel 4 ini, maka pola-pola hubungan yang kuat, lemah, dan negatif, serta keeratan hubngan antar variabel dapat dikenali dengan mudah.

Dari Table 3 dan 4, selain menyajikan koefisien korelasi antara jumlah kelahiran dengan jumlah pejantan dan betina produktif, juga menyajikan koefisien korelasi variabel jumlah betina produktif yang dijual/dipotong/dan yang mati karena kasus penyakit. Pentingnya mengikutkan kedua variabel ini dalam analisis didasarkan pada beberapa pertimbangan. Yaitu adanya larangan pemotongan betina produktif dan dibarengi dengan tindakan penyelamatan batina produktif.

Larangan pemotongan betina produktif didasarkan pada Undang-Undang No. 18 Tahun 2009 tentang Peternakan dan Kesehatan Hewan pasal 18 ayat (2) bahwa ternak ruminansia betina produktif dilarang disembelih karena merupakan penghasil ternak 
yang baik, kecuali untuk keperluan penelitian, pemuliaan atau untuk keperluan pengendalian dan penanggulangan penyakit hewan.

Sedangkan tindakan penyelamatan betina produktif didasarkan pada kebijakan Gubernur Sulawesi Selatan. Maksud dari kedua kebijakan ini, UU No 18 Tahun 1999 dan penyelematan betina produktif, adalah agar setiap betina diberi kesempatan terlebih dulu melahirkan anak guna peningkatan populasi. Hal ini terkait dengan kondisi nasional yang selalu kekurang daging sapi dibanding dengan keutuhan. Akibatnya impor daging sapi dan sapi bakalan terus menerus dilakukan dengan jumlah yang makin meningkat setiap tahunnya. Keadaan seperti ini, sangat tidak sesuai dengan kondisi Indonesia sebagai Negara agraris, tidak sesuai prinsip-prinsip swasembada daging sapi dan produk pertanian lainnya, dan tidak sejalan dengan amanat Undang-Undang nomor 18 Tahun 2012 Tentang Ketahanan Pangan Nasional. Berdasarkan Tabel 3 dan 4, menunjukkan bahwa terdapat tiga pola hubungan terkait dengan jumlah kelahiran, jumlah pejantan dan betina produktif. Pertama, hubungan yang kuat yang ditandai dengan nilai koefisiien korelasi 0,613-719. Kedua, hubungan yang lemah ditandai dengan nilai koefisien korelasi 0,005-0,295. Ketiga, hubungan lemah dan negates ditandai dengan koefisien korelasi 0,105 dam $-0,217$.

Pola Hubungan Kuat. Pola hubungan yang kuat terjadi antara jumlah Kelahiran di satu sisi dengan jumlah Betina Produktif, jumlah Penyelamatan Betina Produktif, dan jumlah Pejantan Produktif di sisi lain. Hal ini dapat dipahami dengan alasan bahwa semakin tinggi jumlah betina produktif, termasuk betina produktif yang diselamatkan, semakin tinggi jumlah kelahiran yang dioperoleh. Demikian pula, semakin tinggi jumlah pejantan, semakin tinggi kelahiran, mengingat kelahiran seekor sapi adalah hasil pembuahan dari seekor pejantan produktif. Hubungan variabel lain juga kuat adalah antara jumlah betina produktif dengan jumlah yang diselamatkan. Pola hubungan ini merupakan aksioma saja, dimana jumlah penyelamatan secara absolut menambahkan jumlah betina produktif yang ada. Tentang hubungan antara jumlah Betina Produktif dengan jumlah Pejantan Produktif, didasarkan pada pertimbangan bahwa untuk setiap proses kelahiran seekor anak sapi harus dikawal dengan seekor pejantan produktif. Meskipun demikian, perbandingan jumlah betina dengan pejantan produktif ini, termasuk keperdulian peternak dalam proses mengawinakan ternaknya masih perlu dikaji lebih lanjut.

Pola Hubungan Lemah. Pola hubungan lemah ini terjadi pada. (1) Jumlah betina produktif yang dijual, dipotong, dan mati dengan jumlah pejantan dan betina produktif. (2) Jumlah pejantan produktif dengan jumlah betina produktif yang diselamtakan. Hal ini mengindikasikan bahwa meskipun masih terjadi penjualan dan pemotongan betina produktif di tingkat peternak, namun tidak mempengaruhi jumlah kelahiran dan jumlah jumlah betina produktif yang ada.

Adapun pola hubungan yang lemah dan negatif adalah jumlah kelahiran dengan jumlah betina produktif yang dijual, dipotong, dan mati. Demikian juga jumlah betina produktif yang dijual, dipotong, dan mati dengan jumlah betina produktif yang diselamatkan. Hal yang penting dalam pola hubungan yang lemah dan negatif ini adalah, bahwa jumlah kelahiran sama sekali tidak dipengaruhi oleh jumlah penjualan, pemotongan, dan kematian serta jumlah penyelamatan betina produktif. Polapola hubungan dari ke lima variabel di atas, baik yang kuat maupun yang lemah dan negatif, dapat dipetakan sebagaimana yang divisualisasikan pada Gambar 2.

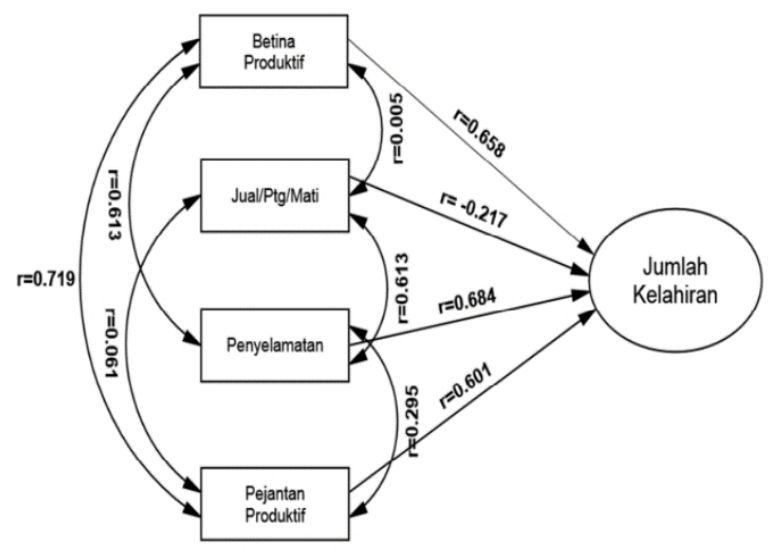

Gambar 2. Pola hubungan antara jumlah kelahiran dengan pejantan dan betina produktif 
Pada Gambar 2 nampak terlihat bahwa hanya 4 variabel yang benar-benar berhubungan langsung dengan jumlah kelahiran sebagai variabel ke 5 . Ke 4 variabel tersebut adalah; jumlah betina produktif, jumlah betina produktif yang dijual, dipotong, dan mati, jumlah betina produktif yang diselamatkan, dan jumlah pejantan produktif. Ke 4 variabel ini juga saling terkait satu dengan lainnya, namun tidak berhubungan langsung dengan jumlah kelahiran. Dengan perkataan lain, bahwa ke empat variabel ini saling terkait, baik sebelum maupun sesudah melakukan hubungan dengan jumlah kelahiran. Kuat dan tidaknya hubungan juga dapat diidentifikasi melalui Gambar 2 dengan melihat nilai koefisen korelasi (r) yang tercamtun pada masing-masing garis penghubung. Jika berdasar pada nilai koefisien ini, maka akan ditemukan hubungan variabel yang kuat, lemah, dan negatif. Namun bukan berarti yang lemah dan yang negatif harus dieliminasi. Inti dari pola hubungan adalah memahami keterkaitan antara satu variabel terhadap yang lainnya, baik secara parsial, maupun secara simultan.

\section{KESIMPULAN}

Terdapat 4 variabel yang berhubungan langsung dengan jumlah kelahiran. Yaitu; (1) jumlah betina produktif, (2) jumlah betina produktif yang dijual, dipotong, dan mati, (3) jumlah betina produktif yang diselamatkan, dan (4) jumlah pejantan produktif. Ke-4 variabel ini juga saling terkait satu dengan lainnya, namun tidak berhubungan langsung dengan jumlah kelahiran. Pola hubungan yang kuat mengindikasikan bahwa jumlah kelahiran sangat erat hubungannya dengan jumlah betina produktif, penyelamatan betina produktif, dan jumlah pejantan. Sedangkan pola hubungan lemah mengindikasikan bahwa jumlah kelahiran tidak berhubungan dengan jumlah betina produktif yang dijual, dipotong, dan yang mati. Ke-4 variabel tersebut secara endogen juga saling terkait satu dengan lainnya, namun tidak berhubungan langsung dengan jumlah kelahiran. Sehingga dinyatakan ke-4 variabel ini saling terkait dan secara simultan mempengaruhi hubungan jumlah kelahiran. Dalam pemetaan pola-pola hubungan ini, tidak dimasudkan bahwa hubungan yang lemah dan negatif harus dieliminasi. Karena inti dari pola hubungan adalah memahami keterkaitan antara satu variabel terhadap yang lainnya, baik secara parsial, maupun secara simultan.

\section{DAFTAR PUSTAKA}

Affandhy L, Dikman DM, dan Aryogi. 2007. Manajemen Perkawinan Sapi Potong. Jakarta: Pusat Penelitian dan Pengembangan Peternakan.

Dirjen Pronak. 2001. Buku Statistik Peternakan. Jakarta: Direktorat Jenderal Bina Produksi Peternakan Departemen Pertanian RI.

Ditjennak. 2010. Blue Print Program Swasembada Daging Sapi 2014. Jakarta: Ditjennak, Kementerian Pertanian.

Haris B. 2010. Analisis Neraca Perdagangan Peternakan dan Swasembada daging sapi 2014. Jurnal Agribisnis dan Pengembangan wilayah. vol 1 (2):1.

Hermanto, Swastika, Dewa KS. 2011. Penguatan Kelompok Tani: Langkah Awal Peningkatan Kesejahteraan Petani, Pusat Sosial Ekonomi dan Kebijakan Pertanian, Bogor. (http://pse.litbang.deptan. go.id/). Diakses Januari 2013.

Ifar dan Bambang AN. 2010. Potensi dan Prospek Usaha Peternakan Sapi Potong di Kawasan Timur Indonesia (KTI) Dalam Kerangka Pengembangan Kawasan Ekonomi Terpadu (KAPET). Semiloka Strategi Pengembangan KAPET di Kawasan Timur Indonesia dalam Menghadapi Era Global, 5-6 Juli. Semarang: Universitas Brawijaya.

Ilham N, Basuno E, Sedjati WK, Ashari S. Nuryanti FB, Dabukke, dan Elizabeth R. 2011. Keragaan, Permasalahan dan Upaya Mendukung Akselerasi Program Swasembada Daging Sapi. Laporan Hasil Penelitian. Jakarta: Pusat Sosial Ekonomi dan Kebijakan Pertanian. Badan Penelitian dan Pengembangan Pertanian.

Kaharudin K, Sagaf, Languha AB, dan Malewa AD, 2010. Analisis Produktivitas 
Sapi Betina Induk Di Sulawesi Tengah. Jurnal Agroland. vol 17 (1):70 -76.

Kementan-BPS. 2011. Rilis Akhir Populasi Sapi Potong dan Kerbau (PSPK). Jakarta: Kementan-BPS.

Kementan. 2012. Cuplikan Blue-Print Swasembada Daging Sapi Nasional 2014. Jakarta: Kementan RI. hal 1-12.

Prajogo UH. 2002. Problem Dan Prospek Pengembangan Usaha Pembibitan Sapi Potong Di Indonesia. Jurnal Litbang Pertanian. Vol 1(1):2.

Rianto E, dan Purbowati E. 2010. Panduan Lengkap Sapi Potong. Jakarta: Penerbit Penebar Swadaya.

Sonjaya H. 2012. Mengkaji Program Sejuta Ekor Sapi di Provinsi Sulawesi Selatan . http://saintis-akademis.blogspot.com. Diakses 24 Juni 2012.
Syamsu JA, Sofyan LA, Mudikdo K., Sa'id EG, dan Laconi EC. 2006. Analisis Potensi Limbah Tanaman Pangan Sebagai Sumber Pakan Ternak Ruminansia di Sulawesi Selatan. Jurnal Ilmiah Ilmu-ilmu Peternakan. vol.VIII (4):1.

Tim Redaksi. 2009. Pedoman Umum Gerakan Pencapaian Populasi Sapi Sejuta Ekor di Sulawesi Selatan Tahun 2013. Makassar: Dinas Peternakan dan Kesehatan Hewan Provinsi Sulawesi Selatan.

Yusdja Y, Sayuti R, Winarso B, Sadikin I dan Muslim C. 2011. Pemantapan Program dan Strategi Kebijakan Peningkatan Produksi Daging Sapi. Bogor: Pusat Penelitian dan Pengembangan Sosial Ekonomi Pertanian, Badan Penelitian dan Pengembangan Pertanian, Departemen Pertanian. 